\title{
Hydrology, Phenology and the USA National Phenology Network
}

Phenology is the study of seasonally-recurring biological events (such as leaf-out, fruit production, and animal reproduction and migration) and how these events are influenced by environmental change. Phenological changes are some of the most sensitive biological indicators of climate change, and also affect nearly all aspects of ecosystem function. Spatially extensive patterns of phenological observations have been closely linked with climate variability. Phenology and hydrology are closely linked and affect one another across a variety of scales, from leaf intercellular spaces to the troposphere, and over periods of seconds to centuries. Ecosystem life cycles and diversity are also influenced by hydrologic processes such as floods and droughts. Therefore, understanding the relationships between hydrology and phenology is increasingly important in understanding how climate change affects biological and physical systems.

A hydrologic budget keeps track of where water is partitioned in the environment, which is important to all aspects of phenology. The budget equation is:

$$
\mathrm{P}-\mathrm{R}-\mathrm{G}-\mathrm{ET}=\triangle \mathrm{S}
$$

where

$$
\begin{aligned}
\mathrm{P} & =\text { precipitation } \\
\mathrm{R} & =\text { runoff } \\
\mathrm{G} & =\text { groundwater recharge } \\
\mathrm{ET} & =\text { evapotranspiration } \\
\triangle \mathrm{S} & =\text { change in water storage }
\end{aligned}
$$

Just as the hydrologic budget can provide valuable information to our understanding of phenology, so also can lifecycle changes occurring within ecosystems provide a feedback linkage to the associated hydrologic systems (table 1).

Climate changes have been predicted for North America by the Intergovernmental Panel on Climate Change. These predicted changes include increases in precipitation in the northern latitudes, more intense precipitation between long drought periods in the southern latitudes, and warmer temperatures throughout North America (Christensen and others, 2007). If precipitation increases or if long periods of drought occur as the result of climate change, partitioning of water within the hydrologic budget may change the structure, function, and services of forest, agricultural, and wetland ecosystems.

Increases and decreases in runoff, or changes in the timing of the runoff events, can affect phenology in numerous ways. For

\begin{tabular}{|c|c|c|}
\hline $\begin{array}{l}\text { Hydrologic budget } \\
\text { process(es) }\end{array}$ & $\begin{array}{c}\text { Process affecting } \\
\text { ecosystem }\end{array}$ & $\begin{array}{l}\text { Life-cycle changes in } \\
\text { ecosystems } \\
\text { (Phenology) }\end{array}$ \\
\hline Precipitation & $\begin{array}{l}\text { Alteration in timing and } \\
\text { intensity of floods and } \\
\text { droughts; nutrient flux in } \\
\text { floodplain and wetlands }\end{array}$ & $\begin{array}{l}\text { Spread of invasive } \\
\text { species; start of season and } \\
\text { ecosystem productivity } \\
\text { altered by influx timing }\end{array}$ \\
\hline $\begin{array}{l}\text { Precipitation and } \\
\text { groundwater } \\
\text { recharge }\end{array}$ & $\begin{array}{l}\text { Inundation or } \\
\text { diminishing of water }\end{array}$ & $\begin{array}{l}\text { Diminished seed } \\
\text { germination or seedling } \\
\text { survival; diminished } \\
\text { hatching of winged } \\
\text { insects; decreased access } \\
\text { to light or air; spreading } \\
\text { of some invasive species }\end{array}$ \\
\hline Runoff & Bed or bank scour & $\begin{array}{l}\text { Egg spawning and } \\
\text { hatching; organism or } \\
\text { community displacement }\end{array}$ \\
\hline $\begin{array}{l}\text { Evapotranspiration } \\
\text { (ET) }\end{array}$ & $\begin{array}{l}\text { Shift in timing and } \\
\text { intensity of ET } \\
\text { causes changes in soil } \\
\text { moisture, wetland } \\
\text { levels, runoff amounts, } \\
\text { and groundwater levels }\end{array}$ & $\begin{array}{l}\text { Green-up and senescense; } \\
\text { wildlife migration; tree } \\
\text { die-off }\end{array}$ \\
\hline $\begin{array}{l}\text { Precipitation and } \\
\text { runoff }\end{array}$ & $\begin{array}{l}\text { Flooding can carry } \\
\text { excessive nutrients into } \\
\text { a water body, causing } \\
\text { eutrophication }\end{array}$ & Algal blooms \\
\hline $\begin{array}{l}\text { Change in water } \\
\text { storage }\end{array}$ & $\begin{array}{l}\text { Glacial melting } \\
\text { due to increasing } \\
\text { temperatures causes } \\
\text { increased runoff and } \\
\text { inundation of sea water }\end{array}$ & $\begin{array}{l}\text { Destruction of habitat; } \\
\text { spread of some invasive } \\
\text { species }\end{array}$ \\
\hline
\end{tabular}
example, in the northwestern United States, recorded average annual air temperatures have risen by about $0.25^{\circ} \mathrm{C}$ per decade since 1950. Warmer temperatures and rain-on-snow events accelerate melting of snow and ice (a change in water storage).
Table 1. Relations between phenology and the hydrologic budget.

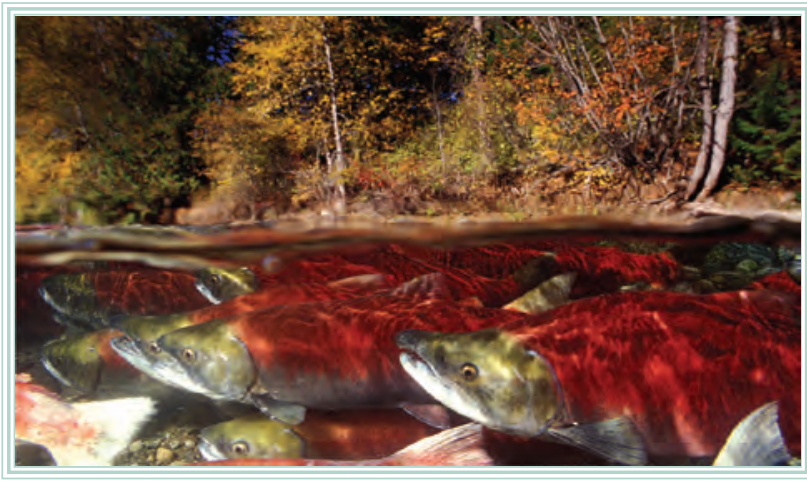

Figure 1. Warmer temperatures may accelerate snow and ice melt causing increases in winter peak runoff and scouring of salmon eggs. Sockeye salmon spawning image courtesy of Brandon Cole, Marine Photography.

Phenology: The study of periodic plant and animal life cycle stages (e.g., leafing, flowering, reproduction, emergence, migration) and how these are influenced by seasonal and interannual variations in climate or environmental conditions.

Seasonality: Non-biological systems also exhibit annual or period stages coupled with changes in environmental conditions (e.g., ice-in and ice-out of lakes and rivers); though this is sometimes termed phenology, the term seasonality is preferred for non-biological events.

Hydrology: The science encompassing the behavior of water as it occurs in the atmosphere, on the surface of the ground, and underground.

Hydrologic Processes: Partitioning of water to and from component of the hydrologic budget.

Hydrologic Budget: An accounting of inflow to, outflow from, and storage in a specified hydrologic system.

Change in Water Storage: A change in location of water storage between the atmosphere, land, and oceans. 
The resulting increases in winter peak flow (runoff) scour streambeds and destroy salmon eggs (fig. 1) (Battin and others, 2007). High runoff during floods causes bed scour, which displaces or destroys aquatic invertebrate populations, drastically reducing food sources for invertebrate consumers. Inundation of floodplains or wetlands earlier than normal may diminish seed germination, seedling survival and recruitment of seed caches in floodplains. Alternatively, abnormally low precipitation causes below-normal flow which can alter the start of spring and diminish the pulse of nutrients to floodplains. Increased runoff, particularly after long dry periods, may generate excess nutrients and algal blooms at critical growth periods for submerged aquatic vegetation. Detritus from algal die-off can bury important food substrates. During high runoff, carbon and nutrients sequestered in wetlands could be released by scour from high energy flows. Alternatively, long periods of below-normal precipitation coupled with increasing temperatures may cause decreases in soil moisture or surface storage, forcing wildlife to migrate or plants to succumb because of the lack of water (fig. 2).

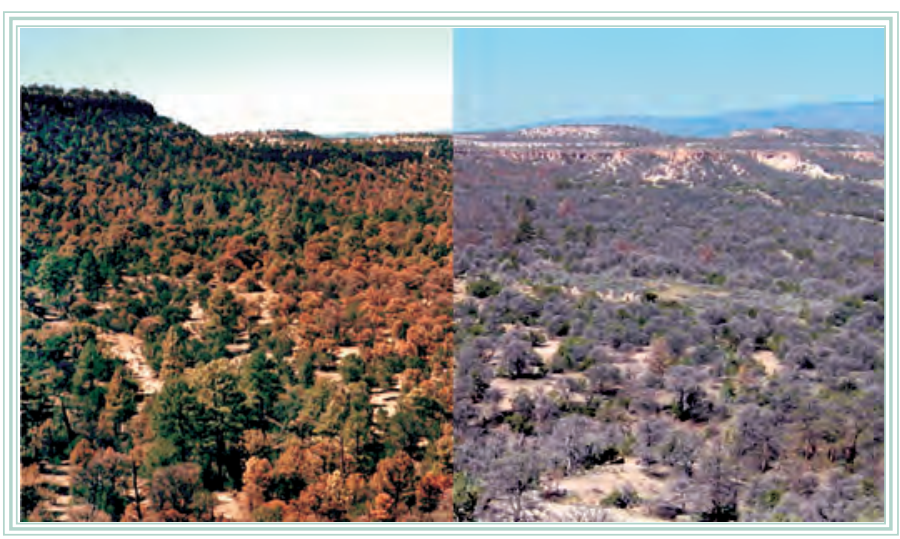

Figure 2. Drought-induced die-off of Pinyon Pine near Los Alamos, NM. Images courtesy of Craig D. Allen, U.S. Geological Survey. From Breshears and others (2009).

Evapotranspiration (ET) is affected by processes that move water from soils to the atmosphere, such as photosynthesis and leaf growth. As temperatures increase, active plant growth occurs earlier in the growing season (Schwartz and others, 2006) and increased ET may reduce the quantity of moisture stored in soils or wetlands, reduce runoff to riparian zones and rivers, reduce groundwater recharge, and lower groundwater levels. In non-arid areas, green-up and senescence (aging) may be accelerated, causing a seasonal shift in the timing and intensity of ET.

Shifts in the timing of the hydroperiod (duration of flooding or inundation) or surface water storage may induce exotic plant and animal invasions. In the Southeast, changes due to warmer temperatures may result in the drying of cypress-dominated riverine wetlands (reduction in water storage). The drying effect may inhibit the growth of new cypress seedlings, while providing an opportunity for colonization by skunkvine, an exotic invasive vine.

Climate-induced lowering or raising of water surfaces (changes in water storage) in the Everglades ecosystem may impact the habitat suitability of resident animals such as the Cape Sable Seaside Sparrow. This sparrow nests near the ground in seasonally inundated marl prairies, and is not tolerant of salt water or salt-tolerant vegetation (Nott and others, 1998). Sea-level rise in low-lying areas may adversely impact reproduction success of the Cape Sable seaside sparrow. Warming temperatures and a sea-level rise will also encourage the spread of the Burmese pythons in the Everglades. Burmese pythons are excellent swimmers, so if sea-level rises, the pythons could increase their range and invasiveness. This likely would increase competition for food with the federally threatened Indigo Snake and contribute to declines in the populations of limpkins (fig. 3).

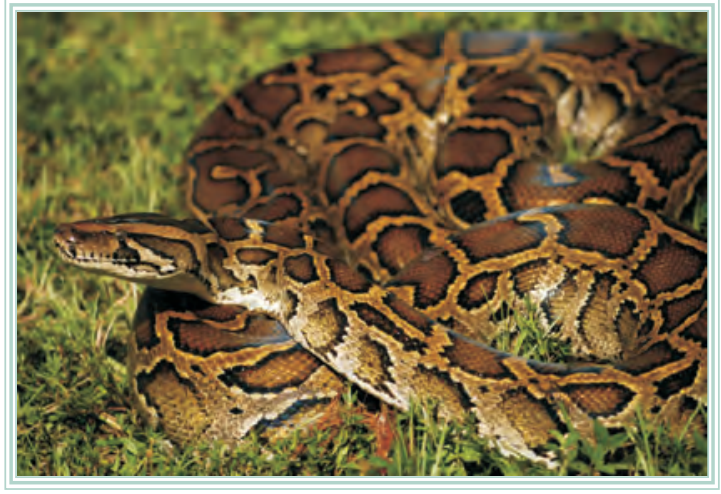

Figure 3. A sea-rise scenario for South Florida could result in expanding the range of the Burmese python. Burmese python in Everglades National Park image courtesy of Wellington Guzman, University of Florida.

Understanding the relation between phenology and hydrology will assist resource managers in controlling invasive species, managing fire potential, managing watersheds and wetlands, and developing strategies to conserve water resources for species adaptation and ecosystem conservation.

The USA National Phenology Network (www.usanpn.org) brings together citizen scientists, government agencies, non-profit groups, educators, and students of all ages to monitor the impact of climate change on life cycle events of plants and animals in the United States. Because climate change predictions forecast major shifts in precipitation and drought occurrence, hydrology is a key component to the understanding of biological changes in life cycles, adaptation, and habitats.

\section{References}

Battin, J., and others, 2007, Projected impacts of climate change on salmon habitat restoration: Proceedings of the National Academy of Sciences, vol. 104, p. 6720-6725.

Breshears, D.D., Myers, O.B., Meyer, C.W., and others, 2009, Tree die-off in response to global change-type drought: mortality insights from a decade of plant water potential measurements: Frontiers in Ecology and the Environment, No. 7, doi: 10.1890/080016.

Christensen, J.H., Hewitson, B., Busuioc, A., and others, 2007, Regional climate projections, in Climate change 2007: The physical science basis. Contribution of working group I to the Fourth Assessment Report of the Intergovernmental Panel on Climate Change, Cambridge University Press, Cambridge, U.K., p. 886-896.

Nott, M.P., Bass, O.L. Jr., Fleming, D.M., and others, 1998, Water levels, rapid vegetational change, and the endangered Cape Sable seaside-sparrow: Animal Conservation, vol. 1, p. 23-32.

Schwartz, M.D., Ahas, R., and Aasa, A., 2006, Onset of spring starting earlier across the northern hemisphere: Global Change Biology, vol. 12, p. 343-351.

Prepared by George R. Kish, Florida Water Science Center-Tampa, FL

For Additional Information:

Jake F. Weltzin, Executive Director

USA National Phenology Network

U.S. Geological Survey

1955 East 6th Street

Tucson, AZ 85721

Telephone: 520-626-3821

E-mail: jweltzin@usgs.gov

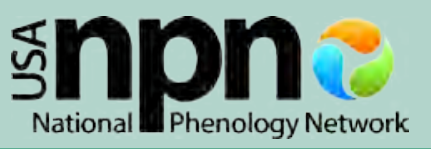

